\title{
Student Outcomes Assessment and Evaluation for ETAC/ABET
}

Dr. Mohammed Abdallah, State University of New York,Polytechnic Inst. 


\title{
Student Outcomes Assessment and Evaluation for ETAC/ABET
}

\author{
M. Abdallah, D. Jones, I. Gherasoiu \\ SUNY POLY
}

\begin{abstract}
ETAC/ABET-accredited programs have demonstrated their excellence during rigorous, objective, periodic reviews conducted by external evaluators. One main part of the accreditation process concerns the student outcomes. It all starts with ETAC/ABET student learning criteria.

An Engineering Technology program must use these learning criteria to develop its own student outcomes. It must document student outcomes that will serve as a reference in judging how the students attain the program educational objectives. A documented and effective process for the periodic review and revision of student outcomes must be available. One challenge is how to present the student outcomes in the self-study report. Each student outcome has to be assessed via a well-developed rubric. Another challenge is to how to summarize all statistics from all different rubrics and report it in a well-written presentation.
\end{abstract}

This paper proposes a simple presentation method to document and present the student outcomes in the self-study report. Data from the Electrical and Computer Engineering Technology programs is used in this paper to illustrate the presentation method.

For each course taught, the instructor evaluates each student on a specific Performance Criteria. These Performance Criteria are derived from the course syllabus and are chosen to capture a specific skill or attribute for a particular student outcome. The faculty member must indicate which course evaluation tools were used (e.g. a specific exam problem, lab exercise, etc), how the data was collected, the threshold used, and the expected level of attainment for that particular Performance Criteria. This information is then captured and summarized on a Course-Level Assessment Form.

For each ETAC/ABET criteria a-k, one or more student outcomes are developed and mapped to the criteria. In this paper, criteria " $C$ " is considered for exemplification purpose. It is the ability to conduct standard tests and measurements; to conduct, analyze, and interpret experiments; and to apply experimental results to improve processes.

A student outcome can be proposed to reflect these criteria. In this paper, a student outcome is proposed to assess criteria " $\mathrm{C}$ " in the Electrical/Computer Engineering Technology program. A new rubric to assess this student outcome is presented along with data collected. Ideas for improvement are reported as well, in order to close the loop followed by effective changes of the evaluation process.

\section{Introduction}


The Electrical Engineering Technology Program has adopted the student learning outcomes listed below. These outcomes were developed in consultation with the faculty and the Industrial Advisory Board. Students that graduate from this program will:

1. Apply modern technology tools, such as software and test equipment, to analyze, simulate, design and improve electrical systems.

2. Apply digital and analog electronics to existing and new components, subsystems, and systems.

3. Apply microprocessors/microcontrollers to existing and new components, subsystems, and systems.

4. Apply programming concepts and application software to general purpose and specific purpose systems.

5. Apply mathematics, physics and sciences to solve technical problems.

6. Communicate effectively, both orally and in writing.

7. Function effectively as part of a project team.

8. Recognize the need for professionalism, excellence, and continuous improvement.

The student outcomes are published on the website, on-line catalog, in front of the department office and on bulletin boards throughout the buildings. These outcomes are assessed at the course level. Both levels of assessment include direct and indirect measures. Table 1 presents the program specific outcomes as they map to the ETAC/ABET [1] student learning criteria [2]. In this paper, criterion " $C$ " is considered and student outcome \#1 is mapped to Criterion " $C$ " as shown in the table. 
Table 1: Mapping of Student Outcomes to the Criteria (a) - (k)

Electrical ET

\begin{tabular}{|c|c|c|c|c|c|c|c|c|c|c|c|}
\hline Program Specific Student Outcomes & 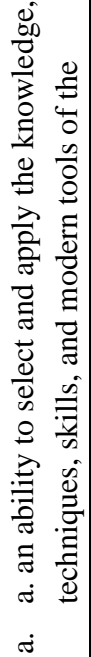 & 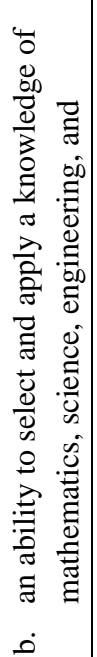 & 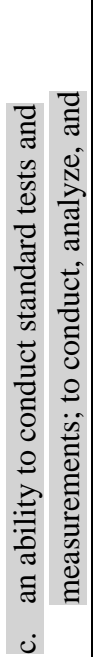 & 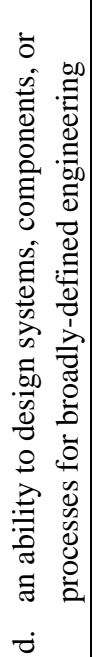 & 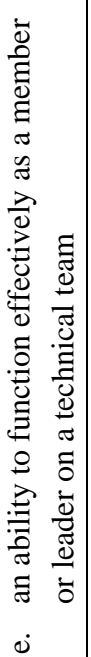 & 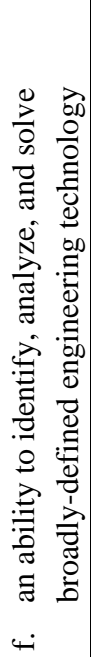 & 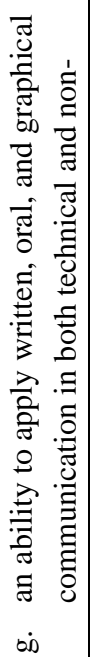 & 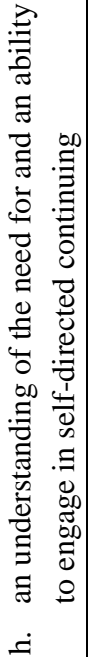 & 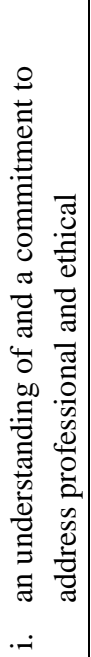 & 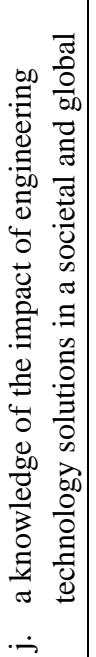 & 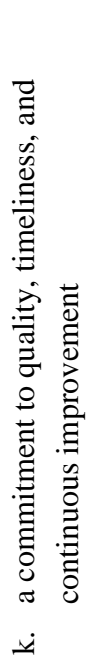 \\
\hline $\begin{array}{l}\text { 1. Apply modern technology tools, such as } \\
\text { software and test equipment, to analyze, } \\
\text { simulate, design and improve electrical systems. }\end{array}$ & $X$ & & $\mathrm{X}$ & & & & & & & & \\
\hline $\begin{array}{l}\text { 2. Apply digital and analog electronics to } \\
\text { existing and new components, subsystems, and } \\
\text { systems. }\end{array}$ & $X$ & & & $X$ & & & & & & & \\
\hline $\begin{array}{l}\text { 3. Apply microprocessors/microcontrollers to } \\
\text { existing and new components, subsystems, and } \\
\text { systems. }\end{array}$ & $X$ & & & & & X & & & & & \\
\hline 4. Apply programming concepts and application & $\mathrm{X}$ & & & & & $\mathrm{X}$ & & & & & \\
\hline
\end{tabular}




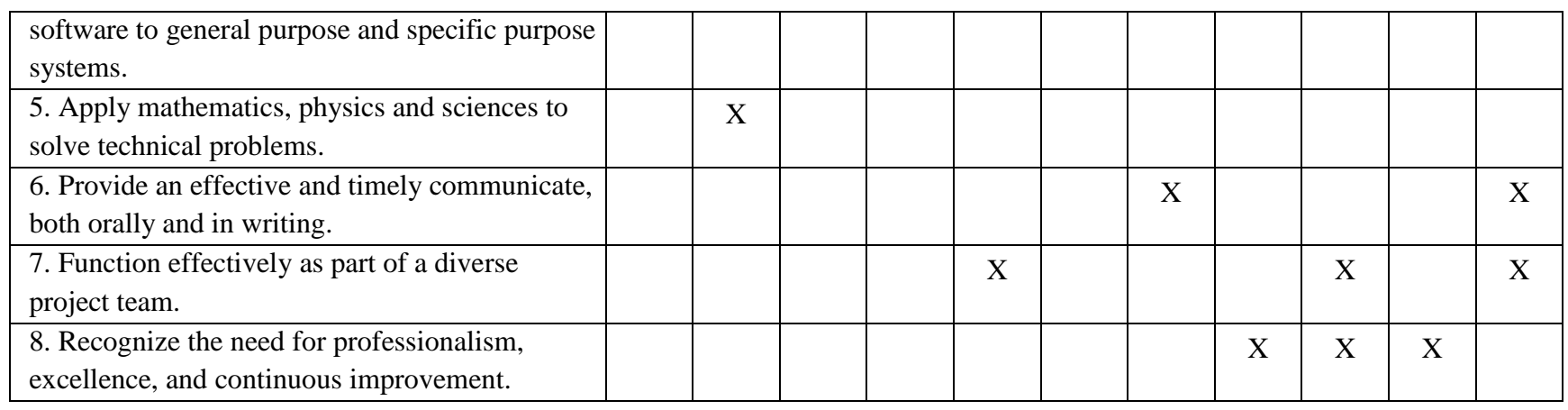




\section{Student Outcomes}

In this section, the student outcome assessment process will be discussed. In addition, the proposed table to present and summarize the collected data will be introduced. Moreover, two important quantities an instructor should determine will be introduced.

\subsection{Student Outcome Assessment Process}

As shown in Figure 1, it is required to assess the knowledge a student gains. Lectures, labs, test, or projects can be used to assess this knowledge. Data will be collected. A certain target should be placed. Then, a comparison should be done between the real percentage and the target percentage. If the real percentage of students who met the standards is above the target, no urgent changes should be made. Otherwise, a feedback action should be done to close the loop and enhance the performance.

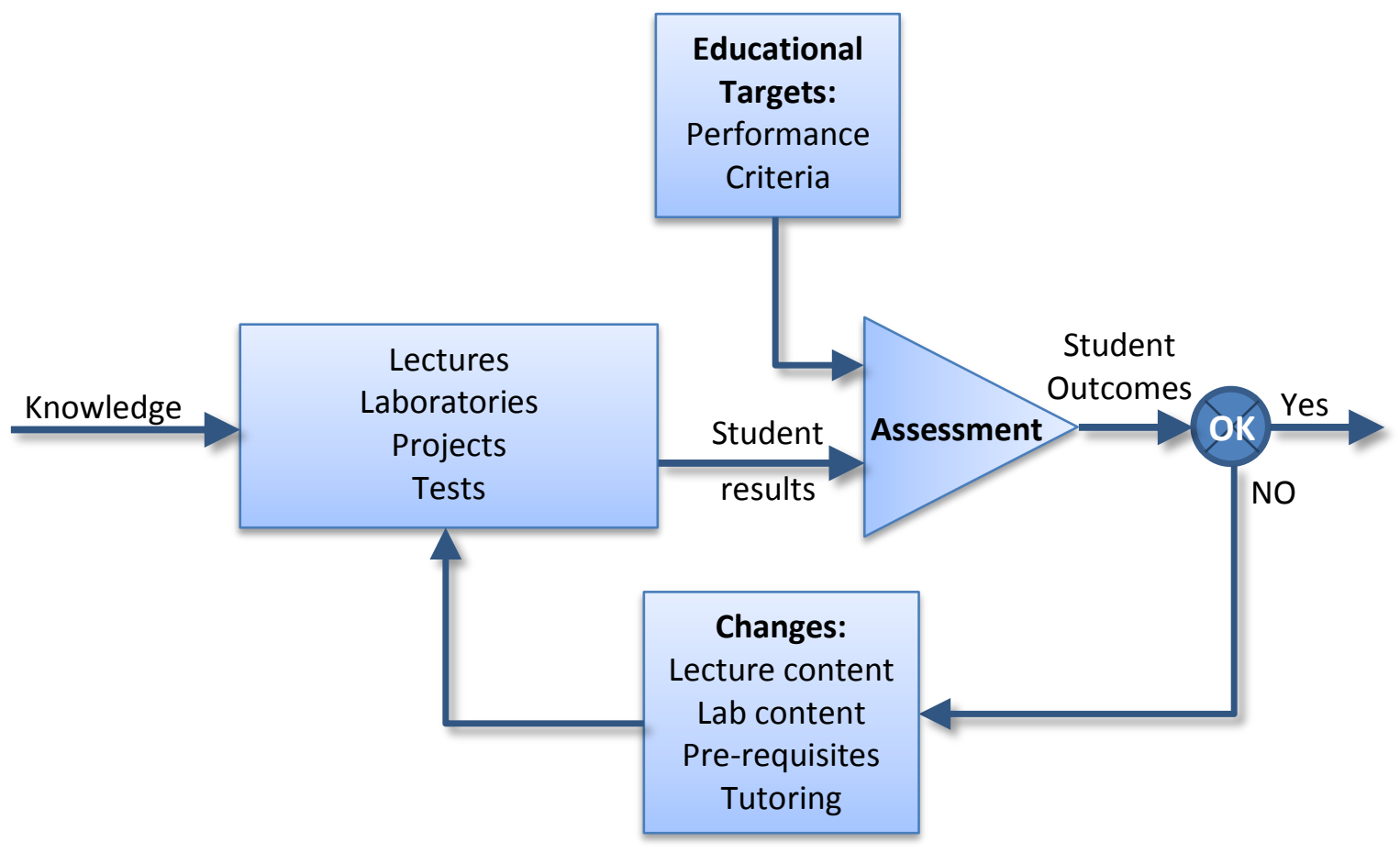

Figure 1. The Student Outcome Assessment Process 


\subsection{Proposed Tables}

Provided below is a description of the assessment process used to gather the data upon which the evaluation of each student outcome is derived.

For each course taught, the instructor evaluates each student on a specific Performance Criteria [3]. The Performance Criteria for Student Outcome 1 is provided in Table 2. Table 2 is considered as the rubric for student outcome \#1. Each performance criterion will be assessed to fall into one of three levels as will be discussed in the next subsection.

These Performance Criteria are derived from the course syllabus and are chosen to capture a specific skill or attribute for a particular student outcome. The faculty member must indicate which course evaluation tools were used (e.g. a specific exam problem, lab exercise, etc), how the data was collected, the threshold used, and the expected level of attainment for that particular Performance Criteria. This information is then captured and summarized on a Course-Level Assessment Form as shown in Table 3.

Table 2: Student Outcome 1 and its Performance Criteria in Electrical Engineering Tech

\begin{tabular}{|c|l|}
\hline Student Outcome & $\begin{array}{l}\text { 1. Apply modern technology tools, such as software and test equipment, to } \\
\text { analyze, simulate, design and improve electrical systems. }\end{array}$ \\
\hline $\begin{array}{c}\text { Students will have successfully achieved this student outcome by } \\
\text { demonstrating one or more of the following: } \\
\text { EET 1.1 ETC 210: Design a combinational logic circuit from a problem } \\
\text { Criteria } \\
\text { description using logic components such as adders, comparators, (dc) } \\
\text { multiplexers, encoders, decoders }\end{array}$ \\
$\begin{array}{l}\text { EET 1.2 ETC 103/203: Design circuits containing diodes, transistors, and } \\
\text { op amps, to meet specified requirements } \\
\text { EET 1.3 ETC 203: Analyze, design and construct a system, component, or } \\
\text { process to meet requirements and/or desired outcome }\end{array}$ \\
\hline
\end{tabular}


Table 3: Course Level Assessment Form

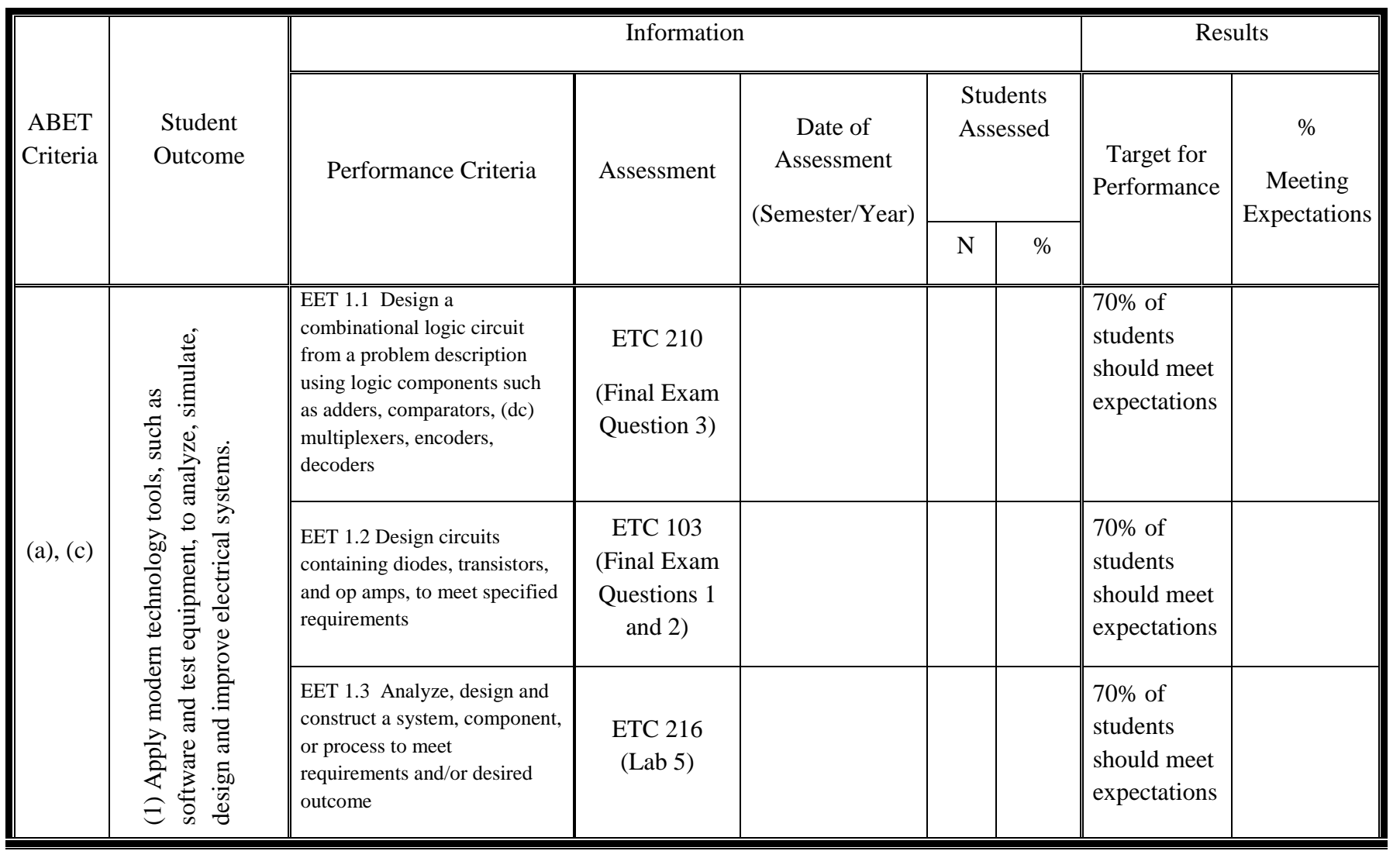


Table 3 is proposed to summarize and represent the data collected to assess student outcome number 1 which is mapped to criteria ' $A$ ' and ' $C$ '. As shown in Table 3, there are different Performance Criteria (EET 1.1, EET 1.2, and EET1.3). Each performance criteria is used to assess a certain aspect of the student outcome. Different materials are collected and assessed. For example, in the first performance criteria (EET 1.1), the question 3 in the final exam is used to assess students' capability to design a combinational logic circuit from a problem description using logic components such as adders, comparators, (dc) multiplexers, encoders, decoders. The instructor uses a proposed rubric to grade this question and reports the following information results: the number of students in this course and the percentage of students taking this exam.

\subsection{Rubrics}

The instructor needs to determine two important items:

A. The instructor should determine the threshold of the score that is considered acceptable in this question.

Based on performance a student demonstrates on the evaluation tool (this would be an assignment, exam question, report, presentation, or whatever the instructor decides to use to measure the level of attainment on the performance criteria), the instructor determines the percentage of students that fall in each of the following categories:

- Level \#1: Did not show minimum acceptable level of achieving objective

- Level \#2: Demonstrated minimum acceptable level of achieving objective

- Level \#3: Demonstrated better than minimum acceptable level

Therefore, students in both levels ( 2 and 3 ) are considered above the threshold the instructor determines. Students in level 1 are considered below this threshold.

B. The instructor needs to determine another quantity which is the target performance of each course/student outcome. An instructor needs to decide the percentage of students who are in levels (2 and 3). In other words, he/she needs to determine the acceptable percentage of students who are above the performance threshold. As shown in Table 3, a $70 \%$ is chosen as the acceptable percentage in these student outcome performance criteria.

Finally, as data analysis results, an instructor will report the actual percentage of students who are above the threshold. If this actual percentage is above the target percentage, so, there is no need to immediately improve this aspect of the student outcome. Otherwise, immediate attention should be paid to this aspect and new improvement actions need to be devised and implemented

\section{Data Analysis and Representation}

It is a challenge to represent all the data and discuss the results in a smooth and easy to read way. For this purpose, Table 3 is introduced. Moreover, Table 4 is prosed to represent the discussion of the data collected and presented in Table 3. 
Table 4. Discussion Representation

\begin{tabular}{|c|c|c|c|c|}
\hline $\begin{array}{c}\text { Performance } \\
\text { Criteria }\end{array}$ & How assessment was performed & $\begin{array}{c}\text { Major Findings of } \\
\text { this Assessment }\end{array}$ & $\begin{array}{l}\text { Action to be taken } \\
\text { in addressing } \\
\text { these assessment } \\
\text { findings }\end{array}$ & $\begin{array}{c}\text { Observation } \\
\text { (Close the } \\
\text { loop) }\end{array}$ \\
\hline EET 1.1 & $\begin{array}{l}\text { Students in ETC } 210 \text { had to } \\
\text { solve the Question } 3 \text { in final } \\
\text { exam. They had to demonstrate } \\
\text { their understanding of } \\
\text { combinational logic circuits. } \\
\text { This exam was graded from 0- } \\
\text { 10. Students with a grade of } 0 \text { - } \\
6 \text { were labeled as Level \#1, } \\
\text { grade 7-9 was Level \#2 and } \\
\text { grade 9-10 was Level \#3. }\end{array}$ & $\begin{array}{l}\text { Depending only } \\
\text { on the final exam } \\
\text { to assess the } \\
\text { performance is } \\
\text { not accurate } \\
\text { because the final } \\
\text { is not } \\
\text { accumulative and } \\
\text { it only focuses on } \\
\text { the last part which } \\
\text { is normally much } \\
\text { difficult than the } \\
\text { previous topics }\end{array}$ & $\begin{array}{l}\text { Use another } \\
\text { assessment } \\
\text { measurement such } \\
\text { as the final grade }\end{array}$ & \\
\hline EET 1.2 & $\begin{array}{l}\text { Students in ETC } 103 / 203 \text { had to } \\
\text { solve the final exam. They had } \\
\text { to demonstrate their } \\
\text { understanding of diodes, } \\
\text { transistors, and op-amps. This } \\
\text { exam question was graded from } \\
\text { 0-10. Students with a grade of } \\
\text { 0-6 were labeled as Level \#1, } \\
\text { grade } 7-9 \text { was Level \#2 and } \\
\text { grade 9-10 was Level \#3. }\end{array}$ & $\begin{array}{l}\text { No significant } \\
\text { findings have } \\
\text { been found at this } \\
\text { time. }\end{array}$ & $\begin{array}{l}\text { Approach seems } \\
\text { to be effective, no } \\
\text { significant } \\
\text { findings drawn. }\end{array}$ & \\
\hline EET 1.3 & $\begin{array}{l}\text { Students in ETC } 216 \text { had to } \\
\text { show their understanding of } \\
\text { Electronics Communications } \\
\text { and test analog modulation } \\
\text { techniques. This final exam } \\
\text { question } 1 \text { was graded from 0- } \\
10 \text {. Students with a grade of } 0 \text { - } \\
7 \text { were labeled as Level \#1, } \\
\text { grade } 8-9 \text { was Level \#2 and } \\
\text { grade } 10 \text { was Level \#3 }\end{array}$ & $\begin{array}{l}\text { In spring } 2012 \text {, } \\
\text { the lab had } \\
\text { limited number of } \\
\text { equipment. The } \\
\text { lab did not have } \\
\text { different domain } \\
\text { equipment. }\end{array}$ & $\begin{array}{l}\text { Buy new lab } \\
\text { equipment. The } \\
\text { merits of the } \\
\text { different domain } \\
\text { equipment is } \\
\text { analyzed } \\
\text { providing the } \\
\text { student with } \\
\text { practical cockpit } \\
\text { time and in-depth } \\
1 \text { knowledge of } \\
\text { advanced } \\
\text { equipment } \\
\text { including test and } \\
\text { measurement }\end{array}$ & $\begin{array}{l}\text { In spring } \\
2013 \text {, the } \\
\text { performance } \\
\text { is improved } \\
\text { as should be } \\
\text { shown above } \\
\text { in Table } 3 .\end{array}$ \\
\hline
\end{tabular}


Finally, after analyzing all the student outcomes, one should be able to present two tables per student outcome such as Tables 3 and 4. Table 5 is proposed to present a summary of all student outcomes in one place. As shown in Table 5, the eight student outcomes can be presented with final results.

Table 5: Summary of Results (EET)

\begin{tabular}{|c|c|c|c|c|c|c|}
\hline \multirow{3}{*}{$\begin{array}{l}\text { ABET } \\
\text { Criteria }\end{array}$} & \multirow{3}{*}{$\begin{array}{l}\text { Student } \\
\text { Outcome }\end{array}$} & \multicolumn{3}{|c|}{ Information } & \multicolumn{2}{|c|}{ Results } \\
\hline & & \multirow{2}{*}{$\begin{array}{c}\text { Date of } \\
\text { Assessment } \\
\text { (Semester/Year) }\end{array}$} & \multicolumn{2}{|c|}{ Students Assessed } & Target Goal & $\begin{array}{l}\text { Meeting } \\
\text { Standard }\end{array}$ \\
\hline & & & $\mathrm{N}$ & $\%$ & $\%$ & $\%$ \\
\hline & & & & & & \\
\hline
\end{tabular}

Each student outcome is evaluated via more than one course and performance indicator. This evaluation is done along different semesters. In Table 5, the summary of the evaluation is presented. The last column, is the result column, and represents the average result of the different performance indicators per student outcome. In the cases that we closed the loop by assessing the same performance indicator a second time (i.e. after one semester or two) to check the improvement, the second performance result is considered in the calculations (i.e. the result after the improvement is taken into account). The number of students that are assessed is determined by the total number of students assessed toward a student outcome.

\section{Documentation and Maintenance of Results}

These results are documented by each faculty member responsible for their respective performance criteria. This information is collected, analyzed at the conclusion of each semester and then maintained by the department chair and program coordinator.

\section{Conclusion}

In general, this paper can be considered as a guideline for any faculty member who is interested in student outcomes assessment. It helps to show how to create a rubric for a given student outcome. Moreover, it proposes a new presentation layout to present all collected data from different courses and semesters in one place. In addition, it shows how to present the summary of all student outcomes and more importantly, how to close the loop and provide ideas of improvement. 


\section{References}

[1] ABET Engineering Accreditation Commission, Criteria for Accrediting Engineering Programs, 2014-2015. Accessed 20 June 2014. Online: http://www.abet.org/etac-criteria-20142015/ (2014).

[2] J. K. Estell. A Heuristic Approach to Assessing Student Outcomes Using Performance Vectors. Proc. of the 2012 ABET Symposium, St. Louis, MO (2012)

[3] G. Rogers, What is a "performance indicator" anyway? Program Assessment of Student Learning. Accessed 10 July 2014. Online:

http://programassessment.blogspot.com/2010/05/what-is-performance-indicator-anyway.html (2010). 